\title{
Ikea Fascism: Metapedia and the Internationalization of Swedish Generic Fascism
}

\author{
Henrik Arnstad \\ Science journalist, specializing in modern history \\ henrik@tricorder.se
}

\begin{abstract}
Today's European movements active within the spectrum of generic fascism have become sophisticated at internationalizing their ideology. This is illustrated in the present article through a study of the Swedish pan-European web encyclopaedia Metapedia, a fascist equivalent of the mainstream Wikipedia, working in the fields of metapolitics and gramscisme de Droite. The article argues that contemporary internationalization goes hand-in-hand with the historical traditions of Swedish fascism since the 1940 s and 1950s, and indeed can be interpreted as a part of Swedish national identity. As such, the idea of Metapedia as 'Ikea Fascism' is not as far-fetched as it would seem, since there is a link between the founder of the multinational Swedish furniture company and the internationalization of Swedish fascism.
\end{abstract}

\section{Keywords}

Metapedia - metapolitics - gramscisme de droite - neo-fascism - internet internationalization - Sweden

In January 2009 the Swedish Justitiekanslern [Chancellor of Justice] investigated the allegedly Nazi web encyclopaedia Metapedia, ${ }^{1}$ following allegations of criminal racial agitation in the article about Adolf Hitler. The investigation, however, did not lead to prosecution since, as the Chancellor stated,

1 http://en.metapedia.org/wiki/Main_Page.

(C) ARNSTAD, $2015 \mid$ DOI 10.1163/22116257-00402002

This is an open access article distributed under the terms of the Creative Commons Attribution 3.0

Unported (CC-BY-NC 3.0) License. http://creativecommons.org/licenses/by/3.0/Brill . com04/26/2023 01:51:28PM 
The reported article contains a biography of Adolf Hitler. In this article, one can read about Adolf Hitler's views of the Jews. The article does not contain any dissociation from Adolf Hitler's anti-Semitic views, but neither does it contain any sympathy for those views, even if it would appear that the author of the article has a positive attitude towards Adolf Hitler. A judgement of the contents of the article, leads to the conclusion that it does not constitute criminal racial agitation, as this crime is defined in the Law. ${ }^{2}$

The most interesting thing about the Swedish website Metapedia - a fascist equivalent of Wikipedia - is not that it has a positive view of Adolf Hitler, which must be considered commonplace for a website of this kind. Rather, the significant characteristic of Metapedia is that it is truly international. Metapedia is available in eighteen languages (as of September 2015), serving radical activists within the generic fascism spectrum - in Europe and elsewhere - with a knowledge bank for their struggle. Since mainstream media, including encyclopaedias, are considered to be infested with lies, there is a need, according to Metapedia, for an alternative: 'Metapedia sets its focus on topics that usually are not covered in ... mainstream encyclopaedias. Metapedia has a metapolitical purpose, to influence the mainstream debate, culture and [general] view of history, the encyclopaedia states. ${ }^{3}$

In this article I will argue that Metapedia is an example of the internationalization and metapoliticitization of what Roger Griffin calls the ideological mutations of the fascist species of radical right.'4 Furthermore, I will argue that this specific example of internationalization of generic fascism, firstly, comes from a long tradition within Swedish fascism, and, secondly, that to the extent that it can be described as a form of entrepreneurial globalization it in fact represents a broader constituent streak of Swedish national identity. For these reasons it is a characteristic expression of contemporary Swedish ultra-nationalism.

2 Anders Ahlberg, 'Artikel om Adolf Hitler friad av JK: Justitiekanslern friar en Hitler-positiv artikel i nätuppslagsverket Metapedia från misstanke om hets mot folkgrupp,' Medievärlden, January 26, 2009, accessed September 30, 2015, http://www.medievarlden.se/etik-a-politik/3 -etik-a-politik/368o-artikel-om-adolf-hitler-friad-av-jk-.

3 'Metapedia,' Metapedia, accessed September 30, 2015, http://en.metapedia.org/wiki/ Metapedia.

4 Roger Griffin, 'Interregnum or Endgame? The Radical Right in the "Post-Fascist" Era,' Journal of Political Ideologies 5 (2000): 163 . 


\section{Metapedia}

In 2004 the Swedish Nazi movement Nordiska förbundet [Nordic Union] was formed by former members of several Nazi and fascist organizations. The movement had close ties with the publishing company Nordiska forrlaget [Nordic Publishing House], and was started in 2002 by ex-skinhead Anders Lagerström. ${ }^{5}$ Unemployed prior to this, Lagerström received training in business administration via the national public unemployment agency and was in fact given government funding to start his own business. The business in question was Nordiska forlaget, which sold Nazi propaganda and white power music, and proved to be an economic success. Thus Lagerström replaced his skinhead clothing with a suit and tie and began presenting himself as a businessman. This proved to be the starting point for both Lagerström's rather successful career and, a couple of years later, also Nordiska förbundet. Between 2005 and 2008 Nordiska förbundet organized an annual festival in Sweden for international neo-Nazis, fascists and right wing extremists: The Nordic Festival. Here, among others, the former Ku Klux Klan-leader David Duke and the German singer of Nazi songs Frank Rennicke made appearances. The internationalization of the particular movement thus became a part of what Griffin has called 'the new sector of international cultural production' which is 'dedicated to keeping alive Nazism as an ideology, either through books glorifying the Nazi period (memoirs, biographies), or, more subtly, through academic journals, monographs, conference papers, and "scientific" reports. ${ }^{6}$ The idea of a fascist web encyclopaedia fits right into this approach and can thus be described as a stroke of genius by Lagerström and his associates. In 2006 Nordiska förbundet and Anders Lagerström started Metapedia, which was to be an international source of knowledge for racist movements and activists. While Nordiska förbundet was terminated in 2010, Metapedia - its most significant contribution - not only survived, but is now thriving. It offers articles that are primarily focused on history, political thought and ideology. Impressively, Metapedia is today available in eighteen languages, even if the number of articles available in each language varies very much. The following languages have the most contributions: ${ }^{7}$

5 Daniel Olsson, 'Från skinnskalle till förlagsredaktör,' Expo (a Swedish anti-racist magazine), March 8, 2006, accessed September 30, 2015, http://expo.se/2006/fran-skinnskalle-tillforlagsredaktor_1494.html.

6 Griffin, 'Interregnum or Endgame?' 169.

7 This according to a counter on the various national Metapedia sites, as of October 12, 2015. The counter for the Hungarian edition as of May 2014 (site is password protected since then). 


$\begin{array}{llr}\text { 1. } & \text { Hungarian } & 146,470 \\ \text { 2. } & \text { German } & 55,859 \\ \text { 3. } & \text { English } & 1,862 \\ \text { 4. } & \text { Swedish } & 10,271 \\ \text { 5. } & \text { Spanish } & 9,167 \\ \text { 6. } & \text { Estonian } & 2,692 \\ \text { 7. } & \text { Rumanian } & 2,393 \\ \text { 8. } & \text { French } & 1,878 \\ \text { 9. } & \text { Portuguese } & 1,629 \\ \text { 10. } & \text { Slovenian } & 935 \\ \text { 11. } & \text { Norwegian } & 602 \\ \text { 12. } & \text { Dutch } & 412\end{array}$

Somewhat surprisingly, as the table shows, the Swedish version of Metapedia is not among the top three. Instead, the Hungarian version is by far the most extensive. This supports the conclusion that Metapedia truly is an ambitious panEuropean project. As such, it is completely in line with the development of modern generic fascism, in which the 'national or ethnic dimension of the struggle for regeneration was not abandoned, but subsumed within a wider context, so that Swedish or American Nazis can feel that the struggle for the rebirth of their nation or homeland is but one theatre in an international race war.8

Studying the traffic Metapedia generates, its global rank according to Alexa ${ }^{9}$ is $63,792 .{ }^{10}$ This is rather modest, comparing to for example the - mainly extremist - Swedish web forum Flashback (ranked 6,045). ${ }^{11}$ Generally in Sweden, national socialist sites like Metapedia are living in the shadow of the web presence of the more 'moderate' Sweden Democrats, above all their semiofficial site Avpixlat (global rank 19,368 on Alexa), thus being one of Sweden's most popular web sites. It would appear that Avpixlat is also a key weapon in a strategy of intimidation against any Swede daring to say anything critical in public about the party. ${ }^{12}$ Swedish journalists, researchers, politicians, civil

Six language versions of Metapedia are lacking information about how many articles are available: Czech, Danish, Greek, Croatian, Icelandic and Macedonian.

8 Griffin, 'Interregnum or Endgame?' 167.

9 http://www.alexa.com.

10 Ranking done February 11, 2015.

11 Flashback is not, however, exclusively racist or ultra nationalistic, but also houses many other threads, generally being an extremist free speech web forum.

12 I have analysed this in: Henrik Arnstad, 'Rätt till yttrandefrihet utan hot, Journalisten.se, February 13, 2015, accessed February 17, 2015, http://www.journalisten.se/debatt/ratt-till -yttrandefrihet-utan-hot. 
servants and ordinary citizens (even children) are the targets of this very well organised industry of intimidation (including death threats). Compared to sites like Avpixlat, the impact in Sweden by Metapedia is miniscule. A guess would be that the mainstream sympathizer of the Sweden Democrats is more interested in hating specific journalists and people of darker colour in general, than being taught ideology or history by Metapedia. However, this does not mean that Metapedia is unimportant. On the contrary, being a tool for an international ultra-nationalist elite (be they Nazis, neo-fascists or radical rightwing populists) gives Metapedia importance which can not be seen in web stats engines like Alexa. They do however show something important about Metapedia, underlining the international scope of the site. Unlike for example Stormfront, receiving almost half of its visitors from the USA, or Flashback and Avpixlat being very much Swedish sites (receiving more than ninety per cent of their visitors from Sweden), Metapedia is truly international, receiving its visitors much more evenly from different countries, as such: ${ }^{13}$

$\begin{array}{lll}\text { 1. } & \text { United States } & 20.6 \% \\ \text { 2. } & \text { Hungary } & 15.4 \% \\ \text { 3. } & \text { Spain } & 9.2 \% \\ \text { 4. } & \text { Sweden } & 5 \cdot 7 \% \\ \text { 5. } & \text { United Kingdom } & 4.3 \%\end{array}$

This international scope does not, however, mean that the arena is free from conflict. Quite the contrary, as has been noted many times, especially regarding how to view Jews. ${ }^{14}$ This conflict in European generic fascism is highly visible, for example, in Metapedia's article about Anders Behring Breivik. Breivik positioned himself within the Islamophobic spectrum of European racism, thus considering Israel a friend and ally in the struggle against Snik-islamisering [creeping Islamization] in Norway. Therefore, the anti-Semitic Metapedia denotes Breivik 'a Zionist freemason and admirer of liberal philosophy', and as such a traitor:

Behring was known to have links to Zionism and was an open supporter of the Zionist State in Palestine, also describing his political views as

13 'How popular is Metapedia?' Alexa, accessed February 11, 2015, http://www.alexa.com/ siteinfo/metapedia.org.

14 Regarding this conflict, see for example Conor Gaffey, 'European far-Right parties "seeking anti-Islam coalition with Jewish groups"', Newsweek, July 14, 2015, accessed October 12, 2015, http://europe.newsweek.com/european-far-right-parties-seeking-anti-islam-coalition -jewish-groups-330300. 
'anti-racist' and 'pro-homosexual' in online writings. ... Soon after the attacks, alternative medias [sic] began to speculate whether the alleged perpetrator was really a 'lone nut' or a patsy for a plan of higher significance. Specifically in relation to Zionism and potential Mossad involvement, the bombing and shooting spree took place on the sixty-fifth anniversary of the King David Hotel bombing; a terrorist attack against anti-Zionist ethnic Europeans. Both events were reported as having killed almost exactly the same number of people; with figures in the gos. ${ }^{15}$

This stance makes Metapedia controversial among European radical rightwing populists and neo-fascists (like the Sweden Democrats ${ }^{16}$ in Sweden), who actively try to distance themselves from any accusations of being linked to Nazism. But this controversy does not stop ultra-nationalists of all inclinations from making use of the 'alternative knowledge' that Metapedia provides whenever it deals with topics that remain dear to all of them. In such cases they show no concern for the anti-Semitism expressed elsewhere on the site. Moreover, since some supporters of the supposedly 'non anti-Semitic' parts of the European racist movements still covertly embrace hate against Jews, the range of users can be assumed to go far beyond traditional Nazis. Clearly, many activists and organizations outside Nazi circles can subscribe to Metapedia's mission statement, which is distinctly ideological and assertive:

Being able to present one's own definitions of concepts as well as interpretations of various phenomena and historical events is a vital part of every metapolitical and cultural struggle. This is more important than ever in these modern times, where many concepts have been distorted and lost their original meaning - which can be regarded as a result of our political opponents' successful cultural struggle.

The possibility to influence the language is vital if you want to shape people's world view. The Frankfurt School and their ideological heirs are good examples in this regard, and have been very successful in stigmatizing previously natural and sound values and attitudes and making them seem pathological by inventing and popularizing concepts such as

15 'Anders Behring Breivik,' Metapedia, accessed May 13, 2014, http://en.metapedia.org/wiki/ Breivik.

16 On the Sweden Democrats as a neo-fascist party, see: Henrik Arnstad, 'Fascism - eller något annat? En ideologianalys av Sverigedemokraterna' [Fascism - or something else? An ideology analysis of the Sweden Democrats], in Sverigedemokraternas svarta bok, ed. Madelene Axelsson and Kristian Borg (Stockholm: Verbal, 2014). 
'xenophobia' and the like. This clearly illustrates the power of language and words, and it is therefore important that we start re-conquering our languages.

Another important purpose of Metapedia is to become a web resource for pro-European activists. Metapedia makes it easy for our cadres to expand their knowledge on various important subjects, and also functions as a searchable reference. ${ }^{17}$

The key concepts above are metapolitics and gramscisme de Droite, or as Metapedia prefers to call it in English, 'Patriotic Gramscianism':

Patriotic Gramscianism (also refered to as Right-wing Gramscism) refers to the conquest by European survivalists of observations on hegemony made by Antonio Gramsci, a cultural Marxist intellectual. The artillery of strategies and observations moulded by Gramsci in regards to ways in which to overturn or subvert European culture and society — intended to deconstruct and eventually destroy the European people from within, like termites gnawing away at the life of the body — is turned around 180 degrees to perform the exact opposite task.

Perhaps the most famous example of this concept of patriotic metapolitical struggle was developed by Alain de Benoist and the think tank GRECE, part of the wider European New Right. The encyclopedia Metapedia in many ways could also be said to have realised the fact of metapolitical struggle. In essence, the strategy forms a pro-European Crusade against the machinations of the Frankfurt School. ${ }^{18}$

The reference to Alain de Benoist is no coincidence, of course, as he is held in extremely high regard in Metapedia-circles. Furthermore, Griffin describes this example of Metapedia-rhetoric as 'the recurrent features of New Right thought', namely 'a right-wing Gramscianism' which recognizes that cultural hegemony must precede political hegemony; the extensive use of intellectuals associated with the 'Conservative Revolution', thus forwarding 'the idea of Europe as a unique cultural homeland which can still be revitalized.'19

17 'Mission statement,' Metapedia, accessed May 13, 2014, http://en.metapedia.org/wiki/ Metapedia:Mission_statement.

18 'Patriotic Gramscianism,' Metapedia, accessed May 13, 2014, http://en.metapedia.org/ wiki/Patriotic_Gramscianism

19 Griffin, 'Interregnum or Endgame?' 170. 
One interesting point regarding Metapedia is financing and the role of millionaire Patrik Brinkmann von Druffel-Egloffstein, who (so rumour has it) has written the article about himself on Metapedia:

a Swedish-German politically active contractor and businessman. Brinkmann founded the Continent Europe Foundation in 2004. . . . Already in the late 199os Brinkmann promoted identitarian opinions and the ideas of Guillaume Faye , Alain de Benoist and Pierre Vial and their significance in a meta-political context. Brinkmann has played an important role as an international coordinator for several identitarian think tanks, organizations and political parties throughout Europe and is partly inspired by the European New Right from France, also known as GRECE. In 2004 Brinkmann founded the Continent Europe Foundation which promotes European culture and identity. The work has its main operations in Germany (including Austria), France , Spain, Italy and Russia.... Already in the 1980 s [he] got familiar with the nationalist movement in Sweden. Since then he has established many personal contact with politicians on the right side. After moving to Germany in 2007 he has been engaged in several political projects in Europe. ${ }^{20}$

Having been described in the Swedish media as 'the patriot in a tail coat', Brinkmann represents the elitist well-to-do part of Europe's extremists on the fascist spectrum. ${ }^{21}$ His wealth is connected to the mineral exploration and mine development company Wiking Mineral. ${ }^{22}$ Having supported various European 'patriotic' politicians, Brinkmann also employs many of his political associates in his company, giving them leading positions in Wiking Mineral. Among them are Mikael Valtersson, former head of administration of the Sweden Democrats, and Daniel Friberg who runs the right-wing-radical publishing company Arktos Media Ltd, situated in Great Britain.

Mentioned above was Brinkmann's pet project, the 'Continent Europe Foundation.' This foundation does not formally exist, according to Swedish authorities, but that does not mean it is unimportant. The idea of this 'foundation' is to create a 'European cooperative project that works for European culture

20 'Patrik Brinkmann,' Metapedia, accessed May 13, 2014, http://en.metapedia.org/wiki/ Patrik_Brinkmann.

21 'Patriot i frack - ett program om en av de rika i Europas ultrahöger', Sveriges radio, November 6, 2011, accessed September 30, 2015, http://sverigesradio.se/sida/avsnitt/53761? programid $=909$.

22 Official website: http://wikingmineral.se/en/. 
and identity', according to Metapedia. ${ }^{23}$ Brinkmann himself writes that 'the foundation "Continent Europa" will bring together scientists of the continent to join and to care for mutual history and future of our European homeland. ${ }^{24}$ Brinkmann is the chairman of this foundation, together with former leading Sweden Democrat Patrik Ehn. Although the foundation boosts several people with academic titles as having been involved 'in the work of the foundation,' it is unknown what that work in practice has consisted of.

\section{Metapedia as 'Ikea Fascism'}

In 1991 I was working as a news reporter for one of the major Swedish daily newspapers, when the Baltic states won their independence from the disintegrating Soviet Union. I interviewed one of the trade ministers from the newly independent states, concerning the future plans for economic progress. The minister formulated his vision with the following words, as I remember them: 'Wherever there is a plane crash in the world, there are always at least one or two Swedes killed. My political goal is that there also will be at least one of my countrymen killed in those crashes.'

These were doubtlessly rather dramatic words, but the point was to convey an admiration for how successfully Swedish business had handled globalization. In short: Swedes are everywhere and so are their companies: Ikea, H\&M, Volvo, Saab, Skanska, Ericsson, Vattenfall and so on. In later years, the world is listening to music via Spotify, keeping in touch via Skype, playing Battlefield 4 or Minecraft, and so on. This brand of Swedish internationalism also exists in the political sphere, dating from the 1950s and 196os, when the 'Swedish Model' was being used actively by the Swedish government to promote the country abroad, especially towards the Anglo-Saxon countries. ${ }^{25}$ This dimension of Swedishness is also visible in Swedish fascism - both historically and present day. As in many European countries, Swedish inter-war fascism was miniscule, due to lack of an available political window. ${ }^{26}$ It was not until after the Second

23 'Continent Europe Foundation,' Metapedia, accessed May 13, 2014, http://en.metapedia .org/wiki/Continent_Europe_Foundation.

24 Ibid.

25 See for example Nikolas Glover, National Relations: Public Diplomacy, National Identity and the Swedish Institute 1945-1970 (Lund: Nordic Academic Press, 2011).

26 I have written more extensively upon this in: Henrik Arnstad, Älskade fascism: de svartbruna rörelsernas ideologi och historia [Fascism, mon amour: ideology and history of the black-and-brown movements] (Stockholm: Norstedt, 2013), 127-131. 
World War that Swedish fascism would make a more notable contribution, and that was on the international level.

One of the Swedish teenage ultra-nationalists during the war was Ikea founder and later legendary Swedish businessman Ingvar Kamprad. In 1942 he came in touch with the most well-known Swedish fascist leader, Per Engdahl $(1909-1994){ }^{27}$ The intellectual Engdahl became organized as early as 1928 in Sveriges Fascistiska Kamporganization [Sweden's Fascist Combat Organization]. During the war, he founded an intellectual fascist organization which in the post-war era lived on by the name of Nysvenska Rörelsen [NSR; The NewSwedish Movement]. Engdahl after the war tried to distance himself from Nazi Germany, claiming in 1945 that his fascism during the war really was 'a defence for all of Europe' but 'this created violent opposition in the dominant Swedish press, and our movement was therefore labelled as Nazism.'28

The internationalization of NSR had already begun in 1945, when Engdahl started an unemployment agency in the city of Malmö for Danish and Norwegian fascists and Nazis fleeing their countries. In 1947 NSR took an additional step, initiating a conference for Nordic fascists, while European fascist leaders were starting to take notice of this new movement, and invitations regarding co-operation began pouring in. At a NSR-conference in May $195^{\circ}$ there were delegates from France, the Netherlands, Belgium, Denmark and Norway. That same year in Italy, the Movimento Sociale Italiano [MSI; Italian Social Movement] organized a pan-European conference in Rome, connecting Engdahl's efforts to even more nationalist parties. In $195^{1}$ Engdahl founded the Europäische Soziale Bewegung (ESB) commonly known as Malmörörelsen [The Malmö Movement], by hosting a conference with the title 'For Europe against Communism.' Notable participants were the British fascist Oswald Mosley, the French intellectual Maurice Bardèche, M si-leader Arturo Michelini and the ex-leader of Hitler-Jugend's propaganda department, Karl-Heinz Priester. The movement focused on abandoning racist ideology and instead concentrated on anti-communism. This decision proved controversial. The French and Swiss delegates insisted upon an 'active politics of race' and antiSemitism, which Engdahl opposed. In 1953 the ESB-program was approved, stating that every member organization (representing Sweden, Denmark,

27 More on Per Engdahl in: Lena Berggren, 'Intellectual Fascism: Per Engdahl and the Formation of "New-Swedish Socialism"', Fascism: Journal of Comparative Fascist Studies 3 (2014): 69-92, accessed September 30, 2015, doi: 10.1163/22116257-00302001.

28 Heléne Lööw, Nazismen i Sverige 1924-1979: pionjärerna, partierna, propagandan [Nazism in Sweden 1924-1979: Pioneers, partys, propaganda] (Stockholm: Ordfront, 2004): 51. My translation. 
Norway, Finland, West Germany, Italy, France, the Netherlands, Switzerland, Austria, Hungary and Spain) should institute a national and social revolution, since democracy had failed to make Europe a third factor in world politics. In the 1950s Engdahl was relatively successful, both on the European level and on the national Swedish level. ${ }^{29}$

During this time, the relationship between Engdahl and Ikea's Ingvar Kamprad deepened. ${ }^{30}$ Kamprad founded his company in 1943. Though the beginnings were humble, Ikea soon grew and in 1947 Kamprad started selling furniture, opening his first department store in 1958. When he married in the 1950s, Per Engdahl was invited as the guest of honour - the fascist leader also gave a speech at the wedding dinner, before which Kamprad stated that he was proud to be a member of Engdahl's political movement. When journalists put the spotlight on Kamprad's fascist past in the 199os, he made a public apology. ${ }^{31}$ But interestingly enough, Kamprad at the same time tries to defend Engdahl's post-war fascist movement, with the argument that it was not Hitler's Nazism: "The truth is that one should call me a fascist.... There were many views in that movement. There were people who were as much anti-Nazis as you and me. ${ }^{32} \mathrm{He}$ also maintains that Engdahl was 'a great man. ${ }^{33}$

The period of Ikea's growth corresponded with the dramatic growth in the Swedish export industry. The importance of foreign trade increased markedly by the end of the decade, growing at twice the pace of Sweden's GNP and contributing twenty per cent to it. Over the course of the 1950s and 196os exports quadrupled, and the Swedish economy became far more dependent on foreign markets than previously, as international specialisation became one of the main forces behind the economy's fast growth. This fact was the backbone in the so-called 'Swedish model' of society's economic and social development. ${ }^{34}$

Engdahl's confidence in establishing his fascist movement and ideas on a European level reflected this growing Swedish confidence during the 1950s. The neutral state of Sweden established itself as a 'third way, between Soviet communism and western (American) capitalism, in its ways of branding the

29 Lööw, Nazismen i Sverige, 51.

30 The relationship between Engdahl and Kamprad has been investigated in: Elisabeth Åsbrink, Och i Wienerwald står träden kvar (Stockholm: Natur \& kultur, 2011).

31 Erik Helmerson, 'Nazism: Kamprad måste berätta hela sanningen,' Dagens Nyheter, August 25, 2011.

32 Tobias Olsson, 'Kamprad: “Jag kallades nazist”,' Svenska Dagbladet, October 28, 2008.

33 Daniel Vergara, 'Kamprad kallar fascist för en stor människa,' Expo, accessed May 13, 2014, http://expo.se/2011/kamprad-kallar-fascist-for-en-stor-manniska_4244.html.

34 Glover, National relations, 75. 
'Swedish Model' abroad. This 'third way' was also visible in Engdahl's vision of a new fascism, without the burdens of biological racism and Hitlerism (granted that those thoughts were also common among many other European post-war fascists). ${ }^{35}$ The general ideology behind Swedish national identity and nationalism became that Sweden could make important contributions to all humanity, to export Swedishness to mankind. And there is no reason to think that Swedish fascism was an exception to this.

There are clear links between the Engdahl movement and today's Swedish fascism, primarily represented by the parliamentary neo-fascist Sweden Democrats (SD). According to the historian Lena Berggren, this party has deep roots in the milieu of race ideology and in 2010 carried through the elections with a party program clearly influenced by the fascist ideologue Per Engdahl' (the party received $5.7 \%$ of the votes and entered parliament - a formidable historic success for Swedish fascism - in the elections of 2014 the party received $12.86 \%) .{ }^{36}$ Unlike other Scandinavian extremist parties, such as the Norwegian Progress Party and the Danish People's Party, the Sweden Democrats did not start as a right-wing populist party in the 1970s, by gathering support among such populist demands as the general reduction of taxation. Instead the Sweden Democrats (founded in 1988) was a continuation of organized Swedish fascism, from the inter-war period, via the post-war Engdahl movement and Nazi organizations:

The Sweden Democrats were initially a focal point for hibernating Nazis, young skinheads and various activists in the Swedish extreme right. Several of the party's local representatives were active in both the Sweden Democrats and openly Nazi groups. In 1995 the Sweden Democrats changed party leader. The old party leader Anders Klarström, which had previously been active in the National Socialist Party Nordic National Party, was replaced by Mikael Jansson, formerly a member of the mainstream agrarian Center Party (Centerpartiet). In connection with the change, efforts began to make the Sweden Democrats an 'ordinary' Swedish party. ${ }^{37}$

The political scientists Anders Hellström and Tom Nilsson describe how the Sweden Democrats acted in 1993:

\footnotetext{
35 Lena Berggren, 'Intellectual Fascism,' 71.

36 Lena Berggren, 'Fascistisk aktivism ska tas på allvar,' Västerbottens-kuriren, March 21, 2014.

37 Daniel Poohl, 'Fakta: Sverigedemokraterna,' Expo [2010], accessed September 30, 2015, http://expo.se/2010/fakta-sverigedemokraterna_3530.html. My translation.
} 
On 30 November 1993, SD organized a demonstration to celebrate the late king of Sweden, Karl XII. Approximately one thousand people took part in the event, which ended in chaos and violence. At the front, the Nazi flag dangled beside the national Swedish flag. On this particular night in Stockholm, the entire city-centre resonated to the crowd's shouts of 'Sieg Heil'. Prior to this, Klarström had been a member of the neo-Nazi party Nordiska Rikspartiet and had a criminal record that included the stealing of ammunition, vandalism and making illegal threats. Other representatives of the party executive had similar backgrounds. Some were members of violent extreme right movements such as the Vitt Ariskt Motstånd [White Aryan Resistance] and Bevara Sverige Svenskt [Keep Sweden Swedish], or involved in the growing industry of white power music. $^{38}$

This growing international industry of white power music became a major source of income for the Swedish neo-Nazi movement in the 1980s and 199os, which continued to have strong international ties on a European level. White power music was 'the soundtrack of the white revolution' 39 in the west and 'for a few short years in the 199o's Sweden was the world's leading nation regarding production of White power music:40 Thus internationalism within Swedish fascism prevailed, made easier by the fact that Sweden during the post-war period de facto (due to its focus on export industry and globalized trade) had become a virtually bilingual country, its population being nearly as fluent in English as in Swedish. The problem was primarily distribution. It was hard to find companies that were willing to manufacture racist cd's, and it was controversial to help these movements with logistics. The internet revolution became a turning point in those hardships, especially in Sweden. Due to a high level of the population having access to personal computers in their homes, Sweden was fast in taking advantage of the new technologies available via the 'information super highway.' This Swedish advantage has prevailed. In 2010 over ninetytwo per cent of the Swedish population was using the internet, making it the country with the highest percentage of internet users in the EU (the European

38 Anders Hellström and Tom Nilsson, “We Are the Good Guys": Ideological Positioning of the Nationalist Party Sverigedemokraterna in Contemporary Swedish politics,' Ethnicities 10 (2010): 57 .

39 Ugo Corte and Bob Edwards, 'White Power Music and the Mobilization of Racist Social Movements,' Music and Arts in Action 1, no. 1 (2008).

40 Mathias Wåg, Från vitmakt-musik till metapolitik [From White power music to meta-politics] (Stockholm: Researchgruppe, 2014. 
average in 2012 being sixty-three per cent).$^{41}$ The Swedish various neo-fascists (including the Sweden Democrats), Nazis and extreme right has been exceptionally successful in utilizing this new technology, their websites and blogs being some of the most frequently visited in the country. ${ }^{42}$

The latest idea of the Metapedia-team is to make a massive multiplayer online computer game, mimicking the Swedish successes with games like Minecraft, the Battlefield-series and Candy Crush. Inspired by World of Warcraft (which happened to be Anders Behring Breivik's favourite game), the idea is to establish fascist ideas in society via the game. As one of the developers has said: 'This idea is genius! To create a politically incorrect computer game. We create obstacles and other things for the gamers, which takes a nationalistic mind to defeat? The gamer feels that he has to think freely and independent to get somewhere in the game, which he might actually do, but this process of thought is totally controlled from the beginning, to promote a certain view of the world!"43

Thus the internationalization of Swedish fascism, manifested by Per Engdahl and Metapedia alike, continues to develop, according to the globalized traits of Swedish nationalism, national identity - and therefore also Swedish ultra-nationalism.

\section{Conclusions}

European ultra-nationalism - be it traditional fascism, neo-fascism or radical right-wing populism - is today a well-established and significant feature of European politics. Is Western liberal democracy losing confidence in itself? Strong European voices claim that freedom of speech is the most important element of a democracy. The problem with this approach is that freedom of speech in practice often means maximizing public racist oppression against Jewish, Muslim or Romani minorities. The lesson of Der Stürmer's role in constructing the gas chambers of Auschwitz-Birkenau seems to have been

41 Internet usage in Europe, Internet world stats, accessed May 13, 2014, http://www.inter -networldstats.com/stats4.htm.

42 The prime un-official website of the Sweden Democrats, Avpixlat, has between 200,000 and 300,000 unique visitors per week, which is impressive considering Sweden's small population of nine million. Nikke Lindqvist, 'Avpixlat större än TV4, GP och Sydsvenskan? Nej, långtifrån [Is Avpixlat bigger than the TV4, GP and Sydsvenskan?]', Nikke Index, accessed May 13, 2014, http://www.lindqvist.com/avpixlat-vs-tv4-gp-sydsvenskan/.

Wåg, 'Från vitmakt-musik till metapolitik.' 
forgotten. In this current process, media like Metapedia play an important role. Being radical and international, it tries to push the common European discourse towards the ultra-nationalistic spectrum, co-operating with national extremist web sites. These sites have proven to be extremely skilful, especially in using Google (they generally show up high in the results of Google searches). As has been noted about the text above, by one of the editors of Fascism:

This is where, I feel, the 'fascist answer to Ikea' metaphor really comes into its own: Metapedia as a wiki is cheap, generic in its visual form, and accessibly DIY. The contributors 'assemble' the edifice themselves, piece by piece. Like Ikea products, Metapedia articles can be produced in countries like Hungary, yet still benefit from the overarching 'brand' (linked to Sweden) that implies a degree of quality and reliability. On social media, I've seen people unwittingly (?) link to Metapedia articles, as if they were as reliable sources on persons or institutions, in order to argue their points. This can only happen because, at first glance, Metapedia looks as familiarly 'reputable' as Wikipedia (same visual 'feel', often copies notes and references, etc.). ${ }^{44}$

If indeed the system of liberal democracy is being challenged by ultra-nationalism in this way, then we need to find ways to counter it. If today's 'truth' is something the citizens of Europe find via Google, then there is all the more reason for being pessimistic about its future.

44 Mail to the author from Fascism (July 31, 2014). 